\title{
Work activities within sustainable development
}

\author{
Francisco Duarte ${ }^{a *}$, Pascal Béguin ${ }^{\mathrm{b}}$, Valérie Pueyo $^{\mathrm{b}}$, Francisco Lima ${ }^{\mathrm{c}}$ \\ ${ }^{a *}$ Universidade Federal do Rio de Janeiro, Rio de Janeiro, RJ, Brazil, fjcmduarte@gmail.com \\ bUniversité Lumière Lyon 2, Lyon, France \\ 'Universidade Federal de Minas Gerais, Minas Gerais, MG, Brazil
}

\begin{abstract}
This paper presents the main results of a Franco-Brazilian Research project entitled "Work, Innovation and Development". The aim is to conceptually consider work activity within sustainable development, and to contribute methodologically towards developing strategies for designing sustainable work systems. After a brief description of the factors and the dimensions that have contributed to the creation of ideas on sustainable development, we will put forward two main approaches for understanding work activity within the context of sustainability, these being: the durability of work activity and the development of work activities for sustainable development. Both approaches are presented and examples are given. This is followed by a discussion of the design of sustainable work systems that focuses particularly on the political and technical dimensions of project management.
\end{abstract}

Keywords

Social development. Innovation. Work. Design process.

\section{Introduction}

Sustainable development requires considerable effort and innovation in order to fully meet the demands of three objectives: social equity, environmental sustainability and economic development. However, work, which is here understood as activity, is lacking from current direction and research focusing on sustainable development. Therefore, the aim of this article is to discuss the relationship between sustainable development and work activities.

The research project "Work, Innovation and Sustainable Development" that was set up between Brazilian and French universities and research centers in 2011, has aimed to make up for this lacuna. The main objective is to conceptually and methodologically contribute towards developing strategies for work systems that facilitate innovation within the perspective of sustainable development. The central idea is to better articulate normative dimensions and technical design of work processes, and to integrate questions relating to long term work transformations in design process as early as possible.

The integration and articulation of the three dimensions (social equality, economic viability and environmental sustainability) required by Sustainable Development involves both methodological choices and political normative dimensions. From the methodological perspective, Sustainable Development requires considerable investment in innovation (Meynard et al., 2006). However, human work is insufficiently considered in the challenge set by the innovative efforts for Sustainable Development. Because work, whether paid or not, should be defined as a fundamental need of populations, innovation for sustained development requires design processes which take into account and contribute toward change and the development of individual and collective human work.

From this perspective, research in ergonomics may be able to make a useful contribution. Ergonomics is "[...] the profession that applies theory, principles, data and methods to design, in order to optimize human well-being and overall system performance [...]" (as defined on the website of the International Ergonomics Association, 2014); the design of work systems has been a key question for research in ergonomics for some time (see for example Helander, 1997; 
Daniellou, 1988). Nevertheless, although there have been commentators calling for ergonomics to be more integrated with sustainability, until recently there has been little in the way of ergonomics investigation or research that is explicitly contextualized as addressing sustained development per se (see also Haslam \& Waterson, 2013). Starting with the basic idea that we need to dynamically articulate on one hand, the innovative process of change for sustained development, and on the other, the development of the historical and social configurations related to a specific human activity (which has its own history, criteria and norms, cf Béguin \& Duarte, 2008), our aim is to contribute to defining and clarifying research guidelines for the future.

This article begins by setting out the concept of sustainable development, and providing some key ideas on the history and different facets of the concept. It will attempt to clarify the relationship between sustainable development and work, and with a focus on the relationship between technology and work will define two lines of research on work activity within the context of sustainability, these being the durability of work activity and the development of work activities for sustainable development. These approaches will be illustrated with examples. On this basis, the paper then proposes design process for sustainable work systems.

\section{Sustainable development: what does it mean?}

The concept of sustainable development is an innovation that is part of the history of thinking about economic and social development, and it is pertinent to recall briefly some of the steps in order to better note the issues involved.

The concept of sustainable development is rooted in a critique of the concept of development, primarily understood as "economic growth", where economic development was understood as progressive and necessary stages (see Rostow, 1952). But at the beginning of the 1960s, some doubts began to arise, which led to emphasizing the importance of taking into account both social change and institutional requirements (in addition to the growth of production and income). The role of education, the "human capital", and the policies for basic sanitation became legitimate questions at the United Nations and its financial institution (the World Bank). In this context, there has been talk of "integrated development", aimed at articulating economic, social, and territorial planning. However, since the 1970s, ecological concerns have been raised about two issues:
- Development in the South has caused severe environmental consequences (degradation of resources, biotypes, soil quality and reducing biodiversity) due to a combination of factors: the inappropriateness of Western technologies, and unfamiliarity with local populations' aims, priorities, and cultural references, among others, all of which have led to worrying levels of degradation (Farvar \& Milton, 1972). This environmental deterioration in itself became an obstacle to improving the situation and standards of living of those populations most disadvantaged.

- In parallel with these concerns regarding land and particularly regarding the social and ecological impact of development, there was another debate which took the form of a world-wide alert: on a global scale the continuation of human economic and demographic development was becoming untenable. "Limits to Growth" were the words used for the Club of Rome's report (Meadows et al., 1972), and Georgescu-Roegen (1979) agreed: tomorrow comes decrease.

In the light of these representations tinged with catastrophe and radicalism (Dupuy, 2002), there was a reaction that began in the 1970s known as "eco-development" that was fuelled by Gunnar Myrdal, Amartya Sen, Colin Clarc and Karl Kapp among others. They wanted to come up with strategies to articulate (i) environmental protection, (ii) economic objectives and (iii) humanist objectives by profoundly reorienting priorities (Sachs, 1980). Four ideas underlie this:

- In a world which has concrete social and economic needs, an approach that only considers human activity as a disturbance of nature, which would be otherwise balanced, is axiologically indefensible and politically unrealistic. Environmental protection should be considered within wider development strategies.

- Development should be founded on meeting the basic material and non-material needs of populations (not only economic returns and solvent demands). It should contribute to the autonomy of individuals as well as populations, in agreement with Sen's (2000) Capability Approach and 1. Illich's (1974) autonomous mode of production, and should not therefore, confuse autonomy with self-sufficiency. Thus, the UNPD (United Nations Development Programme) suggests:

Human development is about much more than the rise or fall of national incomes. It is about creating an environment in which people can develop their full potential and lead productive, creative lives in accord with their needs and interests (United Nations Development Programme, 2001, p 9).

- Technological choices are the key-variables in harmonizing society and nature. The aim is therefore to adapt technologies to the social and natural features of different global regions ("appropriate 
technologies"), rather than trying to adapt resources and populations to technologies invented for and by the developed Western world. This does not mean ignoring contributions from modern science, but requires that technological applications be developed specifically for their local context.

- Development cannot result only from market mechanisms; it requires planning processes on several different levels. At a local level, the aim is to animate and coordinate the populations concerned, and to relate them to both the conception and use of development instruments and practices.

This "eco-developmental" approach was criticized and fought against in the mid 1980s (its content was probably too radical to be supported by the major Western countries), but the expression "sustainable development" (which was initially introduced by the IUCN, and reused in the report by Mme G. H. Brundtland - World Commission on Environment and Development, 1987) finally came under the spotlight.

One can argue that the concept of "sustainable development" is more scientifically ambiguous than the concept of "eco-development" (Harribey, 2002). However, despite its ambiguities, concepts of sustainable development are now debated both North and South, and it is a shared reference for numerous economic and social players (Tubiana, 2000). However, this cannot be reduced to simply a concern for environmental sustainability (and the carbon market). Sustainable development is based on a triad of:

- Social equity, which as mentioned above reiterates the concept of basic well-being and autonomy. Development should be primarily linked to meeting the basic needs (material and non-material) of the most disadvantaged populations.

- Environmental sustainability and the very negative consequences of economic development on the environment (resources, biotypes, soil, biodiversity). Pressure is being rapidly put on ecosystems worldwide, and this is reinforced by awareness of the energy and climate crisis, and gives rise to issues of conservation and creating natural resources.

- Economic viability refers to the idea of a world in which social and economic needs are present, and where an approach that is exclusively centered around nature is untenable axiologically and unrealistic politically. Therefore environmental protection needs to be considered within a more global context of growth and economic development.

\section{Considering work within sustainable development}

The concept of sustainable development stems from numerous issues, which cannot be reduced to economic and environmental questions. Together with the social dimension, work and employment (explicitly designated in the Brundtland report as a need for people) constitute one of the pillars of sustainable development and are therefore a legitimate issue.

However, the field of social equity and work tends to be overshadowed by environmental and economic dimensions. To such an extent, that one could argue that work is the great forgotten dimension of sustainable development (Bazillier, 2011). International bodies have however insisted on these dimensions. In 1998, the International Labor Organization (ILO) defined the "fundamental norms of work" through four dimensions: the right to collective negotiation, the elimination of forced labor, the abolition of child labor and the elimination of discrimination, all of which are currently far from being known on a global scale. This need for a broader consideration of work and the conditions in which it is performed has been reiterated by the $1 \mathrm{LO}$ under the concept of decent work (and this was taken up again in 2007 by the UN), and which in addition to respecting the fundamental norms of work, also embraces three other dimensions: access to social protection, social dialogue and access to a decent job (the right to work).

The reasons why social equity and working conditions appear as a secondary dimension of sustainable development are the subject of many studies. Bazillier (2011) reminds us that this originated with the fact that we most frequently consider economic growth as a factor of improvement concerning social and environmental spheres. This position is clearly seen in the countries of the South: poverty is the main factor that threatens the environment. Such a position assumes that economic growth is put at the service of individuals' needs. Is this actually the case? Authors such as Sachs \& Esteva (1996) and Rist (2007) argue that economic approaches of development are not able to take into account dimensions such as "vital" or "lived". Because their focus is what can be counted, the horizon is economic growth rather than considering what matters to people.

While not casting aside this line of analysis, which focuses on the predominance of economic dimensions over social ones, we consider that the links between work (and not only employment) and sustainable development are currently ill-defined and identified. We would like to contribute to the debate by focusing on the relationship between technology 
and work. More specifically, two approaches seem to have potential for future research. The first looks at the sustainability of work activity related to technological choice. The second looks at the development of work activities in order to implement favorable technology for sustainable development. These two areas will be further developed with an example given for each.

\subsection{Sustainability of work as a dimension of sustainable development}

Work and its conditions of realization are not currently sustainable. The ILO proposal on "decent work" and its attempt to set out the "fundamental norms of work" have already been mentioned above. In many respects, these proposals relate to the countries of the South or to developing countries (child labor has been banned in France since the mid-19 ${ }^{\text {th }}$ century). However, the key questions are not limited to these countries. A topic such as "discrimination at work" (between men and women, or black and white people) is a contemporary question for the countries of the North. In these countries, workers tend to suffer from multiple pathologies such as musculoskeletal disorders and/or severe depressive syndromes that can lead for example to suicide (Bué et al., 2006). In many respects, current forms of work are not sustainable for workers world-wide.

An initial approach is then to look for the conditions that are favorable to work sustainability, i.e. to work that will contribute to health and good life rather than leading to negative repercussions on employee populations. This first approach is clearly related with the Brundtland report, in which work and employment are explicitly designated as "fundamental needs". However, work should not be only thought of as a "need" insofar as it should not be only understood in terms of access to work or employment. Work is rather a "capability", in Sen's understanding of the term (Sen, 1985), in that it has the possibility of "[...] creating an environment in which people can develop their full potential [...] in accord with their needs and interests". An example, from a study in the mining sector in Brazil (Mendes et al., 2013) gives an illustration of this first approach.

The Brazilian mining sector, which is responsible for a significant part of the country's economic autonomy, has seen considerable growth in terms of employment and number of companies involved. The region of Espírito Santo, particularly involved in the research, has seen great development in the number of mining companies and granite and marble quarries since the 1970s. This development is not without an impact on the population. It has allowed improved access to better paid jobs (in comparison with traditional subsistence farming activities); however, at the same time there were questions about the sustainability of work: there were countless work accidents and work-related lung disease (pneumoconiose) linked to dust inhalation (Mendes, 1979; Carneiro et al., 2002; Castro et al., 2005).

As a consequence, a package of new regulations was ushered in from 1978 onwards. Of particular interest was the work hygiene and security regulation for the mining sector that was introduced by the Department of Work and Employment. This regulation, the NR22, makes it obligatory to provide humidification throughout the extraction process and the mineral processing (cutting, smoothing and polishing the marble plaques) so as to remove the dust in the working environment that causes pneumoconioses.

This regulation undeniably shows a desire to encourage sustainable work in one of the country's essential sectors and a source of employment for the population. But its implementation has been systematically problematic and overall appears to have failed.

The introduction of technical humidification led to unexpected difficulties. Two main categories of difficulties emerged:

- The first lies in the near impossibility of reaching the production targets. The presence of water due to the humidification process during cutting hinders operators' ability to check the quality of their work throughout the job. Operators draw the outlines of the cut or for the hole with chalk onto the granite to guide them. Humidification makes these lines hard to see, or even erases them. In addition to this, the presence of water makes it hard to verify the quality of the cut. Operators were obliged to stop production so as to examine the progress of their work and to make new outlines. All this cost important time. Similar problems also came about when polishing the marble. In order to judge the quality of the polish, operators need to verify the level of shine. However, water makes stone shiny. Therefore, operators have to stop polishing and wait for the surface to dry before they can continue. This meant it was impossible to balance production time with quality levels. Employers therefore decided to demand overtime in order to catch up with backlogs, and this led to significant levels of fatigue.

- There were also problems regarding the safety and reliability of the material due to humidification. For example the equipment circulation routes became more slippery, and even at times impassable due to the difficulties in getting rid of the water from the humidification process. Another example is the risk of electric shock caused by the presence of water on electric tools (water that also caused constant 
problems in equipment motors that needed repairing or replacing).

Facing so many "disorders", most of the companies in the field gave up on humidification. However, there were some companies that were successful in using humidification techniques, and it is interesting to look at how they managed these. The research shows that the central issue is what is known as "systemic appropriation": this is the ability to adjust and reconstruct the whole work system, so as to take into account the constraints and difficulties that are encountered by operators using the new technical devices for humidification.

The following is an example from a company that cuts granite surfaces. It has already been mentioned that humidification leads to equipment breaking down, erased outlines and markings for operators, and to difficulties in verifying cuts (as the water creates visual deformations). A series of meetings were held with operators and production managers to try to overcome these difficulties. Two decisions were taken: the first was to acquire new cutting machines (ones that were less sensitive to water and to breakdowns) and to introduce a new outlining stylus to replace the chalk. This stylus made it possible to engrave a line that would remain visible despite the water and, as they later discovered, could also be used to guide the cut. Engraved lines in the stone now guided the cuts that had initially only used visual guides. These evolutions and transformations were not instant; they required operators to learn new skills that were more difficult than had initially been envisaged. However, the company accepted that there would therefore be a temporary reduction in quality. Even with these efforts, there were still certain cuts of granite that were not possible to make within the expected times (for example cuts with rounded edges). Management thereby took two new decisions. The first was to not accept orders that were considered too difficult, given the new cutting techniques that were necessary due to the humidification. The second decision was to set up a specialized production unit, where more experienced operators could undertake the more complex and valuable cuts.

As this short example shows, the use of humidification meant that the constraints experienced by operators at work became decision variables in defining companies' technical and organizational options. To characterize this process it may be useful to discuss systemic appropriation (Mendes et al., 2013): the appropriation of humidification is only possible when the constraints that it generates and its resultant resources are taken into consideration within the context of the overall production system. This systemic appropriation means that the company was able to experiment as in the above example to: (i) develop stone mason know-how, particularly in the area of sensory-motor abilities; (ii) acquire new tools and develop techniques to guide the cuts and, finally, (iii) make organizational adjustments which led to the creation of a new production unit.

\subsection{Supporting activity development during transitions towards sustained development}

In this second orientation of research, one can consider that the issue of sustainable development goes beyond that of work, as it may also for example relate to conserving environmental resources. However, sustainable development creates innovations that induce changes in the work, and therefore the transition to sustainable development depends on its impact on worker activity. This involves developing approaches to innovation that consider transformations of forms of working, evolutions in new professional practices, and adaptations to the demands of sustainable development.

The second example comes from the agricultural sector, which is a study on the reduction of pesticide use in banana plantations in the French Antilles (Temple et al., 2011). Banana production is one of the pillars (along with sugar cane) of the French Antilles' economic development. This production offers socioeconomic benefits (employment, maintenance of a weekly shipping line); however, it is also criticized because of the pollution it causes: bananas are subject to a parasite (black sigatoka), which blackens or darkens the leaves and provokes a significant drop in productivity, and which is combated by using large amounts of pesticides.

In order to deal with this challenge, a series of biotechnological studies were conducted which made it possible to pinpoint certain techniques of controlling the parasite. These techniques are based on three dimensions: (i) developing banana tree production in vitro instead of using grafts and the traditional separation of the trees' roots, (ii) changing land rotation (using fallow land) and (iii) a relatively complex intervention on the shoots (where there is considerable spread of the parasite). Experiments (in vitro and in vivo) show that these techniques in combination met bio-technical and economic expectations. Therefore the decision was made to introduce this new form of production and plantation to the two islands in the French Antilles: Martinique and Guadalupe.

There had been a reduction in the use of pesticides in Guadalupe, but not in Martinique (despite the conditions of growth being essentially the same). More 
particularly, the research shows that this transition from conventional agriculture to one that does not use pesticides requires a change in work activities, which was promoted in Martinique but was rejected in Guadalupe.

This showed that the removal of pesticides requires above all a different relationship with living beings, which in this case were the banana trees. The use of pesticides involves implementing a "virile production strategy": making the plants. The plants are managed and controlled by introducing numerous "entrants" (fertilizers, pesticide, etc.). However, the removal of pesticides calls for a flexible relationship with living beings: the plants have their own autonomy. Thus, the action occurs "gradually" by guiding and facilitating the plants' own growth. To explain this mutation, one can talk about "activity development": the workers need to be offered learning experiences that will influence the way they understand and undertake their work. Three areas of learning are required:

- The first area is centered on observing the plants and the capacity to obtain significant intervention indications. To maintain a flexible relation with the plants and to guide their functioning, it is necessary to understand how to observe the state of the plants and to learn from the observations made. However, this implies an increase in skills among the banana plantation workers, which in turn implies an increase in qualifications, and therein in salary.

- The second area is to direct and to facilitate the plants' own dynamic to influence their growth, and to take into account the temporal and spatial variability of plant situations encountered. This leads to the need to move from standardized and repetitive labor (the Taylorist principle of "scientific management") to autonomous labor, guided by the observation of the condition and the state of the plants and undertaken by semi-autonomous teams able to organize their own work.

- Finally, it appears that use of these techniques that allow control over parasitism produce unexpected effects that need to be considered. In particular, the intensive use of "in vitro" production makes plants sensitive to certain virus. This led firstly to the need to identify specific preventative control techniques (for example, the removal of weeds), and secondly, to altering planting techniques: new equipment (newly equipped tractors, diggers) began to appear in banana plantations.

This development in activities was welcomed and monitored in the banana plantations in Martinique, but in Guadalupe it was rejected. In Martinique, employers took actions related to the need to develop skills: they created training programs and improved salaries (Allaire, 2004). The organization of work activities changed to facilitate the autonomy of collaborators so they can abandon hierarchical production methods (inherited from the $18^{\text {th }}$ century plantation economy). However, landowners in Guadalupe steadfastly rejected the organizational and salary changes implemented by the employers in Martinique, and they continue to maintain production techniques that use pesticides.

\section{Articulating the political and technical dimensions of sustainable development within the design of sustainable work systems}

Both approaches presented are clearly different. In the first, sustainable development is understood with reference to people, well-being and social equity. Good living and working conditions are therefore normative principles for sustainable development. In the second approach, environmental sustainability is the starting point, and it is the consequences on the natural environment that are the normative principles for sustainable development.

In spite of these differences, each approach questions on the one hand the relationship between the descriptive and analytical categories of technical concerns, and on the other, the political categories of living together. In this article, we use the term "political" in its broadest sense of the ancient greek "Politeia": the conditions and rights of the individuals and the relationships (norms, rules, power) established between them. The first approach (the sustainability of work) starts from a political desire for work sustainability. However, as seen in the example of the granite quarries, it is the technical processes of mining and producing that are questioned and redefined. Conversely, in the second case (the development of activities during transition), the starting point is in the production processes and their technological possibilities: the reduction of pesticides offered by the "in vitro" culture. But it is ultimately the relationships between rural workers and landowners that became the focal point. In both cases, the technical and political dimensions of work are in tension and need to be articulated. We share Godard \& Hubert's analysis (2002, p. 13) in considering that "[...] the central issue of sustainable development and its challenges is [...] in the relationships between technology [...] and normative categories". On one hand there is the need to develop innovative technologies, and on the other there is the question of living together at work.

This articulation between technological and political spheres is key to any consideration on sustainable development. However, this articulation still remains largely unexplored within design process, and 
therefore, we wish to make a contribution based on the concepts of project and project management, which are useful if we consider the design of sustainable work systems as something that still needs further work.

Designing work systems for sustained development may be understood as a project, as an objective to be reached, as a desired future to construct, or as a new order to be achieved. Sustainable development stems from such a project in its political dimensions. But this oriented change needs to be implemented in the real world. If we want to achieve or accomplish a project, there is a need for "project management": a process through which the initial intention will be accomplished (see Figure 1).

Project management can be understood as a course of action, which must articulate two planes: the "virtual" and the "reality" (Béguin, 2010). On one side is a representation of "what is desirable" or "what needs to be done": this representation is "virtual". On the other side is the reality of a situation, with its resistances, its contingencies and its own possibilities and impossibilities, all of which must be taken into account in order to implement change. Consequently, there is a need to re-examine the representation and the desired aim through the possibilities or impossibilities of the reality of a setting. Therefore project management is a process during which both the representation of what is desirable and of what is possible must be articulated. (See Figure 2).

For these two poles, "real" and "virtual", can be accepted different conceptual understandings. It is possible to understand them from the perspective of multiple dichotomies: problem setting and problem solving, desirability and possibility, opportunity of choice and determination. However, in all cases, it is necessary to put a purpose and a provisional understanding in tension with its specification in singular situations. Donald Schön's famous metaphor of designing as reflective conversation with the materials of a situation (Schön, 1992) illustrates this tension: the designer, with an aim in mind designs ideas and knowledge, but the situation "responds" and shows unexpected resistance. These serve as a learning base for designers, who have to modify their initial ideas or aims.

This frame is interesting because it provides three ideas for the design of sustainable work systems:

- The first idea suggests that the initial understanding of what is needed cannot and should not be understood as being defined once and for all at the beginning of the design process. There is an initial intention. But due to the resistance of the situation the project undergoes a morphogenesis. Reorientations and changes will take place. If not, the virtual and the real will never converge. From this perspective, it is

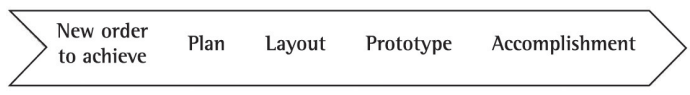

Figure 1. Project management as a transition from a desire in relation to the future towards a change in concrete setting.

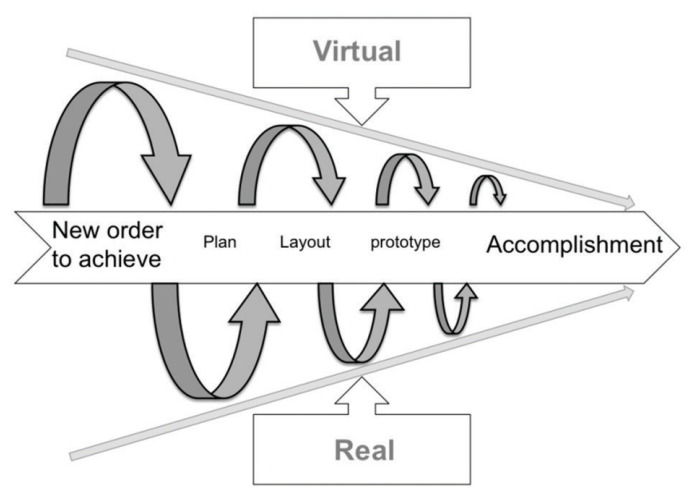

Figure 2. Project management as a process of articulation between the "virtual" and "real".

worth mentioning that not only is the creation of reality guided by the project, but also, the aim and intentions are formed by the revelation itself of what is possible or impossible. A lesson can be learned from this: the direction of the action emerges from its effectuation. As highlighted by Joas (1996), Western philosophies mobilize a "teleological" framework, according to which human acts are understood as the quest for preconceived ends that are then implemented in action. This teleological vision of the project is problematic in several design management approaches. To say that a sustainable work system is something still to be built and is related to design is to call attention to the fact that what is needed is a non-teleological process. It is not possible to abstractify the journey, the path or the construction of experience.

- The second idea is that this non-teleological process is inseparable from the concept of learning. No action can be the pure and simple implementation of prior knowledge. Every action reconstructs the knowledge it needs. This is also the meaning of Schön's metaphor of a reflective conversation with the design situation (Schön, 1983, 1992). The initial idea and knowledge are questioned when confronted with the situation, which "responds" and "is surprised" by its unexpected resistance. These responses are at the base of the learning process. This is why it is so important to establish learning processes based on the real work and the resistance that workers find when they implement solutions provided by designers. When such a learning process is not possible or when the consequences cannot 
be extracted, the transition to a sustainable work system will be impossible.

- The third idea is that this learning process should be seen from a collective (and not only individual) perspective, and should therefore take into account power and the social relations between protagonists. If one returns to the example of the banana plantations in the French Antilles, one sees that changes in work activities were acceptable for the employers in Martinique but not for those in Guadalupe. Foucault (2004) suggested a distinction between two types of process: "normation" and "normalization". The difference between the two allows us to understand what happened in the French Antilles. The process of "normation" is characterized by the fact that some people's knowledge and ideas are transformed into power for other people. The knowledge of some therefore becomes the norm, and those who do not conform are abnormal. In contrast, the concept of "normalization" consists, according to Foucault, of constructing development curves of knowledge so as to locally establish normality. It is a process of "normation" that has prevented change in Martinique: the needs of some were not acceptable to others. Contrastingly, it was a process of normalization that permitted the removal of pesticides in Guadalupe: the actors collectively learned ways of favoring environmental sustainability. Developmental curves of knowledge between the decision makers and those undertaking the actions and who actually experience the work conditions are favorable for transition processes, and means that the knowledge and resistance experienced by the latter will be considered as acceptable ideas and issues for the former. This was also a condition for change in the Brazilian mines.

\section{Conclusion}

It has been suggested that the question of work, its conditions and effects, and its status in the transition to sustainable development is controversial. In general, work tends to be a forgotten variable of sustainable development. This paper situates work in respect to the questions and challenges of sustainability. There appear two distinct issues. The first relates to the sustainability of work. Current forms of work are unsustainable and represent an expense for populations that is also not sustainable. The second issue is in respect to the inevitable changes that production systems will have to embrace in order to reduce the pressure they put on the environment. Work has an impact on these mutations; it influences the trajectories of innovation.

These issues are very distinct from one another. However, analysis reveals in both cases the question of the relations between the political dimensions of living in a work community and the technical dimensions of the production of novelties. The articulation between these two spheres appears to be central in the context of any discussion on sustainable development. It also leads to a question that goes beyond the issue of work. In modern societies, technology has the power to contribute to a better or worse life to a greater or lesser extent; it is outwith the political system, and democratic norms and controls we expected from political institutions (Winner, 1986). This statement leads to a demand for technological democracy and the emergence of a technological "public space" (Feenberg, 1999; Callon et al., 2001). However, unfortunately, in the "technological democracy" it is not easy to think of the role and the place of work: the strategic players are basically the politicians, "the citizens" or "the customers", and are rarely the producers or the workers themselves (Béguin \& Pueyo, 2011). Democratic debate is still far from workplaces.

This paper has for this reason set out several proposals. The aim is to try to understand the technological and political dimensions that are involved in implementing work systems, and to place them within the scope of concept or design approach. An approach such as this also implies taking a stand: it situates issues of work and sustainable development together with those of engineering science and practice. Sustainable development here is considered and placed in a world that is yet to be forged and constructed (in philosophical, sociological and economic terms). At the same time it appears to be necessary to re-examine current forms of project management and change management. It is necessary to persevere with issues on learning, experimentation and, particularly on collective forms of action. These questions on how actions are conducted and on design strategies are not new, and they even resume old themes such as participatory approaches to projects. But the question of sustainable development does now represent a new urgency and presents new issues that oblige us all to reconsider the place of workers and their work.

\section{References}

Allaire, G. (2004). Coopération, qualification professionnelle et régimes de responsabilité: innovation institutionnelle et crise professionnelle en agriculture. Economies et Sociétés, 38(1), 27-65.

Bazillier, R. (2011). Le travail, grand oublié du développement durable. Paris: Le Cavalier Bleu. PMid:21494816.

Béguin, P., \& Duarte F. (2008). A inovação: entre o trabalho dos projetistas e o trabalho dos operadores. Laboreal, 4(2), 10-14. 
Béguin, P. (2010). Conduite de projet et fabrication collective du travail: une approche développementale. Habilitation à diriger des recherches. Bordeaux: Université Bordeaux Segalen.

Béguin, P., \& Pueyo, V. (2011). Quelle place au travail des agriculteurs dans la fabrication d'une agriculture durable. Pistes, 13(1), 1-21. Retrieved from http://pistes.revues. org/1708 http://dx.doi.org/10.4000/pistes.1708

Bué, J., Coutrot, T., \& Puech, 1. (2006). Conditions de travail: les enseignements de vingt ans d'enquête. Toulouse: Octarès.

Callon, M., Lascoumes, P., \& Barthe, Y. (2001). Agir dans un monde incertain: essai sur la démocratie technique. Paris: Seuil.

Carneiro, A. P. S., Santos, M. A. M., Maia, P. V., \& Barreto, S. M. (2002). Câncer de pulmão em trabalhadores expostos à sílica. Journal of Pneumology, 28(4), 233-236.

Castro, H. M., Silva, C. G., \& Vicentin, G. (2005) Estudo das internações hospitalares por pneumoconioses no Brasil, 1984-2003. Revista Brasileira de Epidemiologia, 8(2), 150-160. http://dx.doi.org/10.1590/ S1415-790X2005000200007

Daniellou, F. (1988). Ergonomie et démarche de conception dans les industries de processus continu: quelques étapes-clé. Le Travail Humain, 51(2), 185-193.

Dupuy, J. P. (2002). Pour un catastrophisme éclairé. Paris: Seuil.

Farvar, T., \& Milton, J. P. (1972). The careless technology: ecology and international development. New York: The Natural History Press.

Feenberg, A. (1999). Questioning technology. New-York: Routledge.

Foucault, M. (2004). Sécurité, territoire, population: cours au collège de France, 1977-1978. Paris: Hautes Etudes.

Godard, 0., \& Hubert, B. (2002). Le développement durable et la recherche scientifique à l'INRA. Paris: National Institute of Agricultural Research.

Georgescu-Roegen, N. (1979). Demain la décroissance. Lausanne: Pierre-Marcel Favre.

Harribey, J. M. (2002). La lourdeur insoutenable $d u$ développement capitaliste. France: La Pensée.

Haslam, R., \& Waterson, P. (2013). Ergonomics and sustainability. Ergonomics, 56(3), 343-347. PMid:23547998. http://dx.doi.org/10.1080/00140139.2 013.786555

Helander, M. G. (1997). The human factors profession. In G. Salvendy (Ed.), Handbook of human factors and ergonomics. New York: Wiley

Illich, l. (1974). Medical nemesis. London: Calder \& Boyars. PMid:4133432.

International Ergonomics Association. (2014). What is ergonomics. Retrieved from http://www.iea.cc/whats/

Joas, H. (1996). The creativity of action. Chicago: University of Chicago Press.

Meadows, D. H., Meadows, D. L., Randers, J., \& Behrens, W.W. (1972). Halte à la croissance. Paris: Fayard.
Mendes, R. (1979). Estudo epidemiológico sobre a silicose pulmonar na Região Sudeste do Brasil, através de inquérito em pacientes internados em hospitais de tisiologia. Revista de Saúde Pública, 13(1), 7-19. PMid:462119. http://dx.doi.org/10.1590/S0034-89101979000100002

Mendes, R. W. B., Pueyo, V., Lima, F. P. A., Duarte, F. J. C. M., \& Béguin, P. (2013). 0 agir do trabalhador na prevenção de silicose: a história da umidificação. In A. P. Simonelli \& D. Rodrigues (Eds.), Saúde e trabalho: velhas questões, novas perspectivas. São Paulo: Roca.

Meynard J. M., Aggeri F., Coulon J. B., Habib R., \& Tillon J. P. (2006). Recherches sur la conception de systèmes agricoles innovants. Paris: National Institute of Agricultural Research.

Rist, G. (2007). Le développement: histoire d'une croyance occidentale. Paris: Les Presses de Sciences Po.

Rostow, W. W. (1952). The process of economic growth. New-York: W.W. Norton.

Sachs, W., \& Esteva, G. (1996). Des ruines du développement. Montréal: Écosociété.

Sachs, 1. (1980). Stratégies de l'écodéveloppement. Paris: Ouvrières.

Schön, D. A. (1992). Designing as reflective conversation with the materials of a design situation. Knowledge-Based Systems, 5(1), 3-14.

Schön, D. (1983). The reflective practionner: how professionnels think in action. New York: Basic Books.

Sen, A. (1985). Commodities and capabilities. North-Holland: Oxford India Paperback.

Temple, L., Bakry, F., \& Marie, P. (2011). Innovations sociales pour éliminer les pesticides dans les bananeraies: les conditions de mobilisation du travail. In P. Béguin, B. Dedieu \& E. Sabourin (Coords.), Le travail en agriculture: son organisation et ses valeurs face à l'innovation. Paris: l'Harmattan.

Tubiana, L. (2000). Environnement et développement: l'enjeu pour la France. Rapport au Premier ministre. Paris: La Documentation française.

United Nations Development Programme - UNDP. (2001). Human Development Report 2001: making new technologies work for human development. Oxford: Oxford University Press. Retrieved from http://hdr.undp. org/sites/default/files/reports/262/hdr_2001_en.pdf

World Commission on Environment and Development - WCED. (1987). Our common future. Oxford: Oxford University Press.

Winner, A. (1986). Do artifacts have politics? In the whale and the reactor. Chicago: University of Chicago.

\section{Acknowledgements}

This paper has benefitted from resources provided by the Franco-Brazilian project Capes-Cofecub 702/11 "Work, Innovation and Sustainable Development". 